\title{
SERANGAN BOM BUNUH DIRI DI SURABAYA "FILSAFAT MORAL"
}

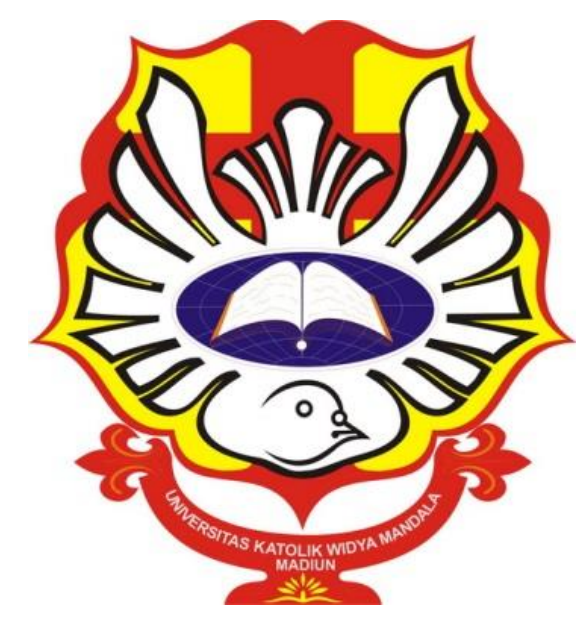

Dosen Pengampu:

Dr. Agustinus W. Dewantara, S.S., M.Hum

Ditulis Oleh:

Anissa Fajar Ariyani (32318005)

PROGRAM STUDI D-III FARMASI

FAKULTAS MATEMATIKA DAN ILMU PENGETAHUAN ALAM

UNIVERSITAS KATOLIK WIDYA MANDALA MADIUN

TAHUN AKADEMIK 2018/2019

Jl. Manggis 15-17 Madiun Telp. (0351)453328,463311,459205

Fax. (0351)453167, http.//www.widyamandala.ac.id

Email : widyamandala@widyamandala.ac.id 


\begin{abstract}
Abstrak
Kasus pengeboman di Surabaya yang meresahakan masyarakat ini dilakukan oleh satu keluarga yang dilakukan di 3 Gereja di Surabaya, bahkan bom bunuh diri ini juga terjadi di rusunawa Wonocolo dan Polrestabes Surabaya. Melalui sudut pandang Actus Humanus, terdapat tiga tindakan yaitu tahu berarti tahu apa yang dilakukannya, mau berarti ada kemauan untuk melakukannya, dan bebas yaitu bebas melakukan dan harus bisa bertanggung jawab atas apa yang dilakukan. Dan juga dapat ditinjau dari hati nurani sesat karena pelaku pengeboman tersebut tidak dapat membedakan perbuatannya tersebut termasuk ke dalam perbuatan yang baik atau perbuatan yang buruk. Tindakan tersebut juga merugikan banyak orang dan pelakunya bisa mendapat pandangan moral yang buruk di mata masyarakat.
\end{abstract}

\title{
Keywords
}

Pengeboman, Moral, Tindakan 


\section{PENDAHULUAN}

\section{Actus Humanus:}

Actus Humanus sendiri identik dengan free act (tindakan bebas). Dalam tindakan yang mengungkapkan kebebasan, manusia adalah pelaku dari tindakannya. Sebagai pelaku, manusia lantas bertanggung jawab atas konsekuensi dari tindakan tersebut.

Kebebasan yang mengandaikan dua hal, yaitu: tahu dan mau. Artinya apabila manusia itu mengetahui dan menghendaki, ia disebut manusia bebas, dan dengan demikian ia bertanggung jawab atasnya. Kehilangan salah satu syarat ini, manusia tidak dapat bertanggung jawab atas tindakannya.

"Tahu" di sini maksudnya bukan hanya pengetahuan yang cukup terhadap objeknya atau sasaran perbuatannya, melainkan juga mengenai dirinya sendiri.

"Mau" juga adalah syarat esensial kebebasan. Kebebasan berarti tidak ada pemaksaan. Akan tetapi kebebasan juga menyangkut pilihan-pilihan yang ada di depannya.

\section{Hati Nurani Sesat:}

Hidup manusia tidak hanya mengalir begitu saja, melainkan juga dibentuk oleh banyak faktor, seperti lingkungan sekitar, tradisi, peraturan, relasi kemanusiaan satu dengan yang lain. Apalagi apa yang disebut hati nurani itu ialah kapasitas ke-elang-an dalam diri manusia. Artinya, sejauh merupakankapasitas, dia tidak bisa melepaskan diri dari konteks/ ruang lingkup dimana manusia hidup/ada/menyejarah.

St.Thomas mengatakan: bila kesesatan hati nurani invincible (tak bisa ditundukkan/tak bisa diatasi) and inculpable (tak bisa dipersalahkan/takbisa dihukum), 
orang dapat luput dari perbuatan yang secara moral jahat. Artinya, bila ia berbuat jahat atas dorongan hatinya yang secara sesat invincible and inculpable, perbuatan jahatnya secara moral tidak bisa ditanggungkan keadaannya. Jika kesesatannya vincible (bisa diatasi) and cupable (bisa dipersalahkan), tanggung jawab perbuatan buruk/jahatnya ada pada si pelaku.

Kesesatan yang culpable ialah kesesatan mengenai apa yang harus diketahui oleh seorang pribadi (jadi dia mestinya tahu), atau kesesatan itu mengalir dari kelalaian atau kesembronoan pada pihak si pelaku (misalnya, karena kesesatan itu dibiasakan). Bila kesesatan itu berhubungan dengan apa yang harus diketahui. Dengan kata lain, tentang apa yang semestinya dia tahu, tetapi dia tidak mau tahu atau membiarkan diri tidak tahu, dia jelas bersalah.

Bila kesesatan hatinya culpable and vincible, dia berdosa, baik apabila mengikuti suara hati nuraninya maupun tidak. Mengikuti suara hati nurani yang sesat culpable and vincible jelas salah, sebab perbuatannya yang tercetus salah atau jahat.

Kesesatan adalah vincible apabila subjek, pada waktu itu, dapat mengoreksinya. Ini berarti dia (subjek itu) paling sedikit memiliki kecurigaan-kecurigaan tertentu bahwa yang sedang dia lakukan itu tidak tidak semestinya atau sewajarnya. Jadi, ada semacam kemungkinan untuk melakukan koreksi. Kalau kemungkinan itu sama sekali tidak ada karena tidak tahu atau karena tidak melihat relevansi moralitasnya, kesesatannya menjadi invincible.

Kesesatan adalah culpable apabila itu merupakan produk dari pemanfaatan kebebasannya secara jahat. Kesesatan vincible tidak mesti merupakan sekaligus kesesatan culpable. Menjadi culpable apabila si pelaku bersikukuh atau bertahan atau sengaja membiarkan diri dalam kesesatannya. 


\section{PENGEBOMAN DI SURABAYA}

\section{Kronologi kejadian:}

\section{Minggu, 13 Mei 2018}

\section{Gereja Santa Maria Tak Bercela (06.30-07.00 WIB)}

Serangan bom pertama terjadi di Gereja Santa Maria Tak Bercela di Jalan Ngagel Madya, Kecamatan Gubeng. Dalam rekaman CCTV yang beredar, terlihat 2 orang kakak beradik Yusuf Fadil (18) dan Firman Halim (16) sedang berboncengan menaiki sepeda motor menuju gereja. Satu pelaku yang dibonceng terlihat membawa ransel yang diduga berisi bom. Sejumlah saksi menyebut serangan terjadi saat pergantian jemaat misa. Ledakan keras terdengar hingga radius 100 meter. Dua pelaku dan lima masyarakat tewas.

\section{Gereja Kristen Indonesia (07.15 WIB)}

Serangan bom kedua terjadi di Gereja Kristen Indonesia Jalan Raya Diponegoro, Surabaya. Sejumlah saksi sempat melihat wanita bercadar membawa dua anak memasuki halaman gereja. Pelaku tersebut Puji Kuswati (43) yang mengajak dua putrinya Fadilah Sari (12) dan Pamela Rizkita (9). Ibu dan dua anaknya yang berupaya masuk ke ruang kebaktian ini sempat dihalau oleh seorang sekuriti di pintu masuk GKI Jalan Diponegoro Surabaya, sebelum kemudian ketiganya meledakkan diri di halaman gereja. Mereka tewas di titik ledakan ini.

\section{Gereja Pantekosta (07.53 WIB)}

Serangan bom ketiga terjadi di Gereja Pantekosta di Jalan Arjuno. Saksi mata menuturkan ledakan terjadi dari tempat parkir kendaraan. Diduga serangan bom mobil. Diketahui bahwa bom dibawa menggunakan mobil Avanza menerobos masuk dengan kecepatan tinggi, menabrak pintu, merangsek ke teras dan lobi gereja kemudian meledak. Api langsung membumbung tinggi di lokasi kejadian. 
Seluruh pelaku rentetan serangan bom di Surabaya dilakukan oleh satu keluarga beranggotakan 6 orang. Kapolri Tito Karnavian dalam koferensi persnya menyatakan bahwa keluarga ini baru saja datang dari Suriah dan merupakan simpatisan Negara Islam Irak dan Syam (ISIS) dan merupakan jaringan Jamaah Ansharut Daulah (JAD) dan Jamaah Ansharut Tauhid (JAT).

Dalam pembagian tugasnya Dita Oepriyanto adalah pengemudi Avanza yang menabrak GPPS Jemaat Sawahan. Sebelum melakukan kejahatan, Dita menurunkan istrinya Puji Kuswati dan dua anak perempuannya di GKI Diponegoro. Ketiga orang ini telah dipasangkan tiga buah bom yang dililitkan dipinggang. Dalam keterangan polisi, jenazah istri dan kedua anaknya rusak di bagian perut.

Sedangkan pelaku di Gereja Katolik Santa Maria Tak Bercela diduga merupakan anak laki-laki Dita. Mereka mengendarai sepeda motor dan memangku bom yang akan diledakkan.

Negara Islam Irak dan Syam melalui kantor beritanya, Amaq News Agency, menyatakan bahwa mereka bertanggung jawab atas serangan ini.

\section{Rusunawa Wonocolo, Surabaya (20.00 WIB)}

Malam pada hari yang sama, terjadi ledakan di sebuah Rumah Susun Sederhana Sewa (Rusunawa) Wonocolo, kawasan sepanjang, Sidoarjo, Jawa Timur. Ledakan tersebut terjadi pada Blok B lantai 5 dan terdengar hingga lima kali dan dikonfirmasi merupakan sebuah ledakan bom rakitan yang dibuat oleh penghuni rusunawa. Setelah ledakan pertama, polisi langsung mendatangi tempat kejadian dan menemukan Anton Febrianto sedang memegang alat pemicu bom. Dalam insiden ini setidaknya tiga orang tewas, dua diantaranya tewas akibat ledakan bom, yakni istri Anton, Puspitasari beserta anak tertuanya, Hilta Aulia Rahman, serta Anton yang tewas tertembak polisi akibat perlawanan. Tiga anak lainnya terluka dibawa ke Rumah Sakit Siti Kodijah. 


\section{Senin, 14 Mei 2018}

\section{Polrestabes Surabaya (08.50 WIB)}

Kepala Bidang Humas PoldaJawa Timur Kombes Frans Barung menyatakan bahwa pada Senin, 14 Mei 2018 pukul 08.50 WIB, sebuah ledakan terdengar di depan Polrestabes Surabaya. Berdasarkan rekaman CCTV, ledakan terjadi di pintu gerbang Polrestabes Surabaya ketika sebuah mobil mini-bus dan dua buah sepeda motor akan diperiksa petugas. Ledakan berasal dari sepeda motor bernomor polisi L $6629 \mathrm{NN}$ dan L $3559 \mathrm{G}$ yang setidaknya membuat empat pelaku tewas dan sepuluh warga dan polisi terluka. Petugas polisi juga menyelamatkan seorang anak perempuan pelaku dari lokasi kejadian.

\section{Analisis kasus:}

Actus Humanus yang berkaitan dengan tindakan "bebas" berarti setiap manusia bebas melakukan semua tindakannya dan harus berani bertanggung jawab atas semua apa yang dilakukannya. Dalam kebebasan Actus Humanus terdapat dua hal, yang pertama "tahu", yaitu pelaku tersebut seharusnya sudah mengetahui dan menilai tindakan yang dilakukannya tersebut mengarah kepada tindakan kebaikan/keburukan.

"mau", yang berarti pelaku tersebut melakukan semua tindakannya atas dasar kemauan sehingga mereka berani untuk melakukan bom bunuh diri tersebut.

Dari kasus tersebut pelaku yang sudah di cuci otaknya melakukan bom bunuh diri untuk melaksanakan jihad yang menurutnya bisa membawanya masuk surga sehingga kehilangan akal dan tidak memikirkan toleransi terhadap sesama dan dampak yang ditimbulkan merugikan orang lain, merusak fasilitas umum dan bahkan menghilangkan nyawa orang lain. Sehingga pelaku harus menerima konsekuensi dan mempertanggungjawabkan kelakuannya bukan lagi melalui 
hukum di dunia melainkan juga hukum di akhirat dan itu bisa lebih berat hukumannya. Selain mendapat hukuman juga mendapat dosa atas perbuatannya yang termasuk dalam pembunuhan, dan mendapat pandangan jelek dari masyarakat mempunyai moral yang buruk dan tidak berperikemanusiaan terhadap dirinya dan keluarga.

Sedangkan ditinjau dari hati nurani sesat, manusia itu mempunyai hati nurani dan keyakinan bahwa hati nurani itu suara Tuhan, tetapi tidak semua hati nurani itu baik karena hati nurani tersebut dapat dipengaruhi oleh beberapa faktor terutama keluarga dan lingkungan disekitarnya. Apabila manusia tersebut hidup di dalam lingkungan yang baik maka manusia tersebut akan mempunyai sikap dan perilaku baik, sedangkan apabila hidup di dalam lingkungan yang kurang baik maka manusia tersebut bisa saja mempunyai perilaku yang kurang baik karena terpengaruh oleh lingkungan disekitarnya. Sama halnya kasus tersebut sebelum melakukan bom bunuh diri, satu keluarga ini baru datang dari Suriah dan merupakan simpatisan dari Negara Islam Irak dan Syam (ISIS) dan kelompok ini dicap sebagai organisasi teroris oleh PBB.

Dari kejadian pengeboman di Surabaya tersebut pelaku dikatakan termasuk dalam hati nurani sesat karena pelaku pengeboman tersebut sudah tidak dapat membedakan perbuatannya tersebut termasuk ke dalam perbuatan yang baik atau perbuatan yang buruk, sehingga tidak bisa mengetahui jika perbuatan yang dilakukan itu tidak semestinya/sewajarnya.

Walaupun menurut pelaku tindakan yang dilakukan tersebut benar, jika menurut moralitas obyektif, pelaku tersebut bersalah karena sudah melanggar hukum, membuat keresahan masyarakat dan bahkan menghilangkan nyawa orang lain. Dan sedangkan menurut moralitas subyektif pelaku tidak bisa menghindar dari sanksi ini karena berurusan dengan dirinya dan Tuhan, dan pelaku tersebut dan keluarga bisa mendapat sanksi sosial dari masyarakat. 


\section{DAFTAR PUSTAKA}

Dewantara, A. (2017). Filsafat Moral (Pergumulan Etis Keseharian Hidup Manusia).

Dewantara, A. (2017). Diskursus Filsafat Pancasila Dewasa Ini.

https://id.wikipedia.org/wiki/Pengeboman Surabaya

https://news.detik.com/berita/d-4358370/terorisme-terlaknat-2018-bom-sekeluarga-

mengguncang-surabaya

https://www.merdeka.com/peristiwa/ini-kronologi-lengkap-serangan-bom-bunuh-diri-di-3gereja-surabaya.html 